\title{
19. DATA REPORT: NO SIGNIFICANT OCCURRENCES OF DIATOMS, SILICOFLAGELLATES, OR EBRIDIANS IN LOWER EOCENE THROUGH LOWER MIOCENE SEDIMENTS OF THE SOUTHEAST GREENLAND MARGIN ${ }^{1}$
}

\author{
Reed P. Scherer ${ }^{2}$
}

\section{INTRODUCTION}

Sediments recovered at Deep Sea Drilling Project (DSDP) Leg 38 Sites 336-340, and 342 established that the Norwegian-Greenland Sea, north of the Greenland-Scotland Ridge, was host to rich diatom, silicoflagellate, and ebridian communities during much of the middle to late Paleogene (Dzinoridze et al., 1978; Schrader and Fenner, 1976; Martini and Müller, 1976). Recent studies by Scherer and Koç (1996) and Locker (1996), which resulted from drilling in the northern Norwegian-Greenland Sea during Ocean Drilling Program (ODP) Leg 151, contributed significant new data toward the development of a regional late Paleogene biosiliceous phytoplankton biostratigraphy, although the recovered stratigraphic record remains incomplete.

High Paleogene diatom productivity in relatively shallow waters in the high northern latitudes is evident from diatomaceous sediments known from outcrop (Benda, 1972; Homann, 1991) and borehole studies (Fenner, 1994) on Jutland (Denmark) and from outcrop studies in western Kazakhstan and the Urals (e.g., Gleser and Posnova, 1964; Krotov and Shibkova, 1959; Gleser et al., 1974; 1992). Diatomaceous Eocene sediments were recovered in a single short core from the Alpha Ridge in the central Arctic Ocean (Dell'Agnese and Clark, 1994). Lower Paleogene diatoms that occur in the Russian and Danish deposits have been documented as reworked specimens in glacial sediments in northern Scandinavia (Cleve-Euler, 1941; Tynni, 1982) and in glacial-marine sediments of the northern Barents Sea (Grunow, 1884; Polyakova et al., 1992; Myhre, Thiede, Firth, et al., 1995; Scherer and Koç, 1996). These occurrences suggest that diatomaceous sediments were deposited across the broad, shallow seas that covered the northern European lowlands during Paleogene highstands of sea level. These deposits were subsequently eroded, transported and redeposited during Pleistocene glacial events in Fennoscandia, in most cases leaving no trace of the original strata.

Paleogene biosiliceous phytoplankton microfossils also have been documented in the high latitude North Atlantic region, south of the Greenland-Scotland Ridge. Sporadic occurrences of Eocene diatom-bearing sediments have been reported, including those from DSDP drilling at Sites 553 (Leg 81) (Baldauf, 1984; Palmer, 1984) and 405 (Leg 48) on the Rockall Plateau, Sites 400 and 402 (Leg 48) in the Bay of Biscay, and Site 384 (Leg 43) on the North American continental margin, south of the Grand Banks (all in Palmer, 1984). Upper upper Eocene to lower lower Oligocene diatomaceous sediments were recovered from the Labrador Sea at DSDP Site 112 (Leg 12; Burckle, 1972) and ODP Site 647 (Leg 105) (Baldauf and Monjanel, 1989).

'Saunders, A.D., Larsen, H.C., and Wise, S.W., Jr. (Eds.), 1998. Proc. ODP, Sci. Results, 152: College Station, TX (Ocean Drilling Program).

${ }^{2}$ Institute of Earth Sciences, Uppsala University, Villavägen 16, S-752 36 Uppsala, Sweden.Reed.Scherer@natgeog.uu.se

\author{
METHODS AND MATERIALS
}

During ODP Leg 152, drilling along the East Greenland Margin recovered shallow-water Paleogene sediments from Holes 914B, 915A, 916A, and 917A, and relatively deep-water Paleogene sediments from Hole 918D. Five samples from Hole 914B, 12 samples from Hole 915A, and 81 samples from Hole 918D were received for biostratigraphic and paleoenvironmental analysis of diatoms in Eocene, Oligocene, and lower Miocene sediments (Table 1). Samples from Hole 914B include lower Oligocene massive sandy silts with nearshore macrofossil debris (Larsen, Saunders, Clift, et al., 1994). Samples from Hole 915A include middle to upper Eocene shallow marine silts and clays, containing variable concentrations of biogenic carbonate. Samples from Hole 918D include lower Miocene to lower Eocene calcareous nannofossil-bearing mudstones. This sedimentary section was very poorly recovered; nevertheless, there is strong evidence from calcareous nannofossil biostratigraphy for a major unconformity between middle Eocene and upper Oligocene sediments between Cores 152-918D-88R and 86R (Larsen, Saunders, Clift, et al., 1994). Smear slides were prepared from all samples for initial evaluation of diatom occurrence, abundance, and preservation. Table 1 is a list of samples examined.

\section{RESULTS AND DISCUSSION}

This investigation showed an absence of identifiable diatom, silicoflagellate, and ebridian debris in all samples examined. The only example of these microfossil groups noted includes trace quantities of biosiliceous debris replaced by pyrite, in Sample 152-918D-92R$2,34-36 \mathrm{~cm}$. None of these rare fragments can be identified. The absence of biosiliceous microfossils in these sediments obviously prevented application of any biostratigraphic scheme. It can be assumed that the lack of these fossils is a result of some combination of low biosiliceous productivity relative to the sediment accumulation rate, and a water column and pore waters that were corrosive to opaline silica. Some combination of these conditions prevailed despite the high abundance of biosiliceous debris of these ages on the northern side of the Greenland-Scotland Ridge, in the Norwegian-Greenland Sea.

\section{ACKNOWLEDGMENTS}

This investigation received support from USSAC.

\section{REFERENCES}

Baldauf, J.G., 1984. Cenozoic diatom biostratigraphy and paleoceanography of the Rockall Plateau region, North Atlantic, Deep Sea Drilling Project Leg 81. In Roberts, D.G., Schnitker, D., et al., Init. Repts. DSDP, 81: Washington (U.S. Govt. Printing Office), 439-478.

Baldauf, J.G., and Monjanel, A.L., 1989. An Oligocene diatom biostratigraphy for the Labrador Sea: DSDP Site 112 and ODP Hole 647A. In Srivastava, S.P., Arthur, M.A., Clement, B., et al., Proc. ODP, Sci. Results, 105: College Station, TX (Ocean Drilling Program), 323-347. 
Benda, L., 1972. The diatoms of the Moler Formation of Denmark (Lower Eocene): a preliminary report. Nova Hedwigia Beih., 39:251-266.

Burckle, L.H., 1972. Summary of diatoms in Hole 112. In Laughton, A.S., Berggren, W.A., et al., Init. Repts. DSDP, 12: Washington (U.S. Govt. Printing Office), 176-177.

Cleve-Euler, A., 1941. Alttertiäre Diatomeen und Silicoflagellaten im Inneren schwedens, gefunden und gezeichtnet von Ake Berg, beschrieben von Asterid Cleve-Euler. Palaeontographica, 92:165-212.

Dell'Agnese, D.J., and Clark, D.L., 1994. Siliceous microfossils from the warm Late Cretaceous and early Cenozoic Arctic Ocean. J. Paleontol., 68:31-47.

Dzinoridze, R.N., Jousé, A.P., Koroleva-Golikova, G.S., Kozlova, G.E., Nagaeva, G.S., Petrushevskaya, M.G., and Strelnikova, N.I., 1978. Diatom and radiolarian Cenozoic stratigraphy, Norwegian Basin; DSDP Leg 38. In Talwani, M., Udintsev, G., et al., Init. Repts. DSDP, 38, 39, 40, 41 (Suppl.): Washington (U.S. Govt. Printing Office), 289-427.

Fenner, J., 1994. Diatoms of the Fur Formation, their taxonomy and biostratigraphic interpretation: results from the Harre borehole, Denmark. Aarh. Geosci., 1:99-163.

Gleser, S.I., Jousé, A.P., Makarova, I.V., Proshkina-Lavrenko A.I., and Sheshukova-Poretzkaya, V.S., 1974. The Diatoms of the USSR: Leningrad (Nauka). (in Russian)

Gleser, S.I., Makarova, I.V., Moisseeva, A.I., and Nikolaev, V., 1992. The Diatoms of the USSR, Fossil and Recent (Vol. 2): Stephanodiscaceae, Ectodictyonaceae, Paraliaceae, Radialiplicataceae, Pseudopodosiraceae, Trochosiraceae, Melosiraceae, Aulacosiraceae: St. Petersberg (Nauka). (in Russian)

Gleser, S.I., and Posnova, A.N., 1964. Diatomeae Novae Marinae ex Eoceno Kazachstaniae occidentalis. Novitates Systematicae plantarum non vascularum. Academia Scientiarum URSS, Inst. Botanicum Nomine V.L. Komarovii: Moscow, Leningrad (NAUKA), 59-68.

Grunow, A., 1884. Die Diatomeen von Franz-Josefs-Land. Denkschr. Kaiserl. Akad. Wiss., Wien, Mathem.-Naturw. Classe, 48:53-112.

Homann, M., 1991. Die diatomeen der Fur Formation (Alttertiär, Limfjord/ Dänemark) Geol. Jahrb. Reihe A, 123:1-285.

Krotov, A.I., and Shibkova, K.G., 1959. Species novae diatomacearum e paleogeno montium uralensium. Botan. Mater. Otd. Sporovykh Rast., Botan. Inst., Akad. Nauk SSSR, 12:112-129.
Larsen, H.C., Saunders, A.D., Clift, P.D., et al., 1994. Proc. ODP, Init. Repts., 152: College Station, TX (Ocean Drilling Program).

Locker, S., 1996. Cenozoic siliceous flagellates from the Fram Strait and the East Greenland Margin: biostratigraphic and paleoceanographic results. In Thiede, J., Myhre, A.M., Firth, J.V., Johnson, G.L., and Ruddiman, W.F. (Eds.), Proc. ODP, Sci. Results, 151: College Station, TX (Ocean Drilling Program), 101-124.

Martini, E., and Müller, C., 1976. Eocene to Pleistocene silicoflagellates from the Norwegian-Greenland Sea (DSDP Leg 38). In Talwani, M., Udintsev, G., et al., Init. Repts. DSDP, 38: Washington (U.S. Govt. Printing Office), 857-895.

Myhre, A.M., Thiede, J., Firth, J.V., et al., 1995. Proc. ODP, Init. Repts., 151: College Station, TX (Ocean Drilling Program).

Palmer, A.J.M., 1984. Implications and biostratigraphy in the Eocene North Atlantic Ocean [Ph.D. dissert.]. Univ. of South Carolina, Columbia.

Polyakova, E.J., Pavlidis, Y.A., and Levin, A.A., 1992. The features of diatom thanatocoenoses of surface sediments of the Barents Sea shelf. Oceanology, 32:166-175. (in Russian)

Scherer, P.P., and Koç, N., 1996. Late Paleogene diatom biostratigraphy and paleoenvironments of the northern Norwegian-Greenland Sea. In Thiede, J., Myhre, A.M., Firth, J.V., Johnson, G.L., and Ruddiman, W.F. (Eds.), Proc. ODP, Sci. Results, 151: College Station, TX (Ocean Drilling Program), 75-99.

Schrader, H.-J., and Fenner, J., 1976. Norwegian Sea Cenozoic diatom biostratigraphy and taxonomy. In Talwani, M., Udintsev, G., et al., Init. Repts. DSDP, 38: Washington (U.S. Govt. Printing Office), 921-1099.

Tynni, R., 1982. The Reflection of Geological Evolution in Tertiary and Interglacial Diatoms and Silicoflagellates in Finnish Lapland. Geol. Surv. Finland, 320

Date of initial receipt: 1 August 1995

Date of acceptance: 26 February 1996

Ms 152SR-243

Table 1. Samples examined for Paleogene and lower Miocene diatoms and siliceous flagellates.

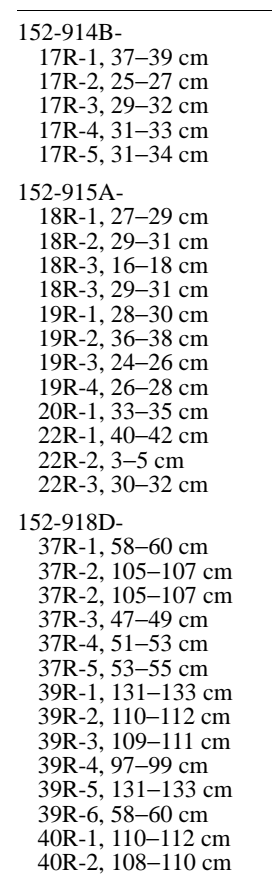

40R-3, 109-112 cm

40R-4, 39-41 cm

$40 \mathrm{R}-5,24-26 \mathrm{~cm}$

40R-6, 32-34 cm

$41 \mathrm{R}-1,110-112 \mathrm{~cm}$

$41 \mathrm{R}-2,115-117 \mathrm{~cm}$

41R-3, 118-120 cm

41R-4, 106-108 cm

$41 \mathrm{R}-5,104-106 \mathrm{~cm}$

$41 \mathrm{R}-6,25-27 \mathrm{~cm}$

44R-1, 91-93 cm

RR $2,89-91 \mathrm{~cm}$

$44 \mathrm{R}-3,91-93 \mathrm{~cm}$

4 R $-3,91-93 \mathrm{~cm}$

$44 \mathrm{R}-5,117-120 \mathrm{~cm}$

$51 \mathrm{R}-1,17-18 \mathrm{~cm}$

51R-4, 27-28 cm

51R-5, 20-22 cm

51R-6, 34-36 cm

52R-1, 99-101 cm

$52 \mathrm{R}-1,99-101 \mathrm{~cm}$

$52 \mathrm{R}-2,66-68 \mathrm{~cm}$
$52 \mathrm{R}-3,124-127 \mathrm{~cm}$

52R-4, 126- $128 \mathrm{~cm}$

$52 \mathrm{R}-5,29-31 \mathrm{~cm}$

53R-1, 59-61 cm

53R-2, 98-100 cm

53R-3, 109-111 cm

53R-4, 97-99 cm

$53 \mathrm{R}-5,53-55 \mathrm{~cm}$

$53 \mathrm{R}-5,53-55 \mathrm{~cm}$

$53 \mathrm{R}-6,32-35 \mathrm{~cm}$
$53 \mathrm{R}-7,98-100 \mathrm{~cm}$

$53 \mathrm{R}-7,98-100 \mathrm{~cm}$
$55 \mathrm{R}-1,39-41 \mathrm{~cm}$

$55 \mathrm{R}-2,86-88 \mathrm{~cm}$

$55 \mathrm{R}-3,112-114 \mathrm{~cm}$

55R-3, 31-33 cm
55R-5, 14-16 cm 55R-6, 25-27 cm $57 \mathrm{R}-1,72-74 \mathrm{~cm}$ $57 \mathrm{R}-2,69-71 \mathrm{~cm}$ $57 \mathrm{R}-3,66-68 \mathrm{~cm}$ 62R-1, 35-37 cm 62R-2, 40-42 cm 63R-1, 40-44 cm 63R-2, 46-48 cm 68R-1, 16-18 cm 68R-1, 16-18 cm $72 \mathrm{R}-1,56-58 \mathrm{~cm}$ 74R-1, 56-58 cm $74 \mathrm{R}-1,32-34 \mathrm{~cm}$ 75R-1, 31-33 cm $75 \mathrm{R}-4,28-30 \mathrm{~cm}$ 76R-1, 23-25 cm 84R-1, 68-70 cm $86 \mathrm{R}-1,11-13 \mathrm{~cm}$ 88R-1, 53-55 cm $88 \mathrm{R}-1,53-55 \mathrm{~cm}$ $88 \mathrm{R}-1,53-55 \mathrm{~cm}$ 89R-1, 43-44 cm 89R-2, 41-43 cm 89R-3, 42-44 cm 89R-4, 15-17 cm 90R-3, 62-64 cm 90R-3, 68-70 cm 91R-1, 65-67 cm 92R-1, $36-38 \mathrm{~cm}$ 92R-1, 36-38 cm 92R-2, 34-36 cm 93R-1, 86-88 cm 96R-3, 82-84 cm 96R-7, 89-91 cm 